\title{
UMA NOVA GEOGRAFIA ECONÓMICA ${ }^{1}$
}

\author{
TERESA BARATA SALGUEIRO ${ }^{2}$
}

A geografia humana ora se preocupa com a distribuição das populações e dos fenómenos de carácter social, ora estuda a distribuição das actividades económicas e a sua relação com o espaço. Independentemente da perspectiva de estudo, ao longo do tempo sempre temos encontrado uma geografia social por um lado, e uma geografia económica, por outro.

Influenciados pelo determinismo e pela noção de que a terra era uma fonte de recursos que os homens utilizam de acordo com a sua capacidade técnica e organização social, os manuais de geografia económica começaram por ser um repertório das riquezas existentes nas várias regiões ou uma enumeração sobre os sítios onde se encontram certos produtos, tipos de empresas, e actividades económicas. $\mathrm{Na}$ explicação para os padrões encontrados a acessibilidade e a facilidade de transportes adquirem desde cedo uma posição destacada, não obstante a importância que as diferentes linhas teóricas dão a um ou outro conjunto de factores.

Nas últimas décadas a abertura da geografia a outras ciências intensificou-se, em larga medida, devido aos desafios que o aparecimento de disciplinas de fronteira, como a ciência regional e outras, começaram a colocar. Ao mesmo tempo, o mundo conhece um conjunto impressionante de mudanças que, sob a égide da economia, estão alterando as nossas vidas a um ritmo veloz.

Sem discutir a ideia subjacente às revoluções científicas de Kuhn, importa notar que há períodos fortes e fracos de produção em determinados campos disciplinares. Os períodos fortes são aqueles em que surgem novos termos, novas problemáticas, se avançam hipóteses e explicações novas, a que depois se seguem numerosos trabalhos de estudo de casos. À medida que estes períodos avançam acumulam-se muitas ideias interessantes ainda não estruturadas num conjunto coerente, mas suficientemente inovadoras para criar um distanciamento progressivo em relação ao saber feito e disponível nos manuais. Este distanciamento é particu-

\footnotetext{
1 MÉndez, R. (1997) Geografia Económica. La lógica espacial del capitalismo global. Editora Ariel. Barcelona.

2 Professora Catedrática da Faculdade de Letras, Universidade de Lisboa. Investigadora do Centro de Estudos Geográficos da Universidade de Lisboa. Centro de Estudos Geográficos, Faculdade de Letras, Cidade Universitária, 1699 LISBOA Codex. Tel.: (351-1) 7965162; Fax: (351-1) 7960063.
} 
larmente sentido e angustiante para os professores que acompanham a produção científica borbulhante mas têm de recomendar aos seus alunos os "velhos" manuais. Vão introduzindo os novos temas, e organizando o material disperso procurando não entrar em grande conflito com o saber instituído. Os esforços que isto implica estão por vezes na origem de uma nova geração de manuais, como este que Ricardo Mendez acaba de publicar.

A hipótese central que Ricardo Mendez apresenta para a sua obra é a de que "assistimos al inicio de una nueva etapa en la evolución del sistema económico a la que puede calificarse como de capitalismo global,... provoca importantes cambios en la lógica espacial de las empresas y eso se traduce en la relocalización de numerosas actividades, la densificación de las redes de flujos y la aparición de nuevas formas de desigualdad"(xiii).

Ricardo Mendez tem uma visão dinâmica da sociedade e por isso parte da mudança, acentua a importância da inovação tecnológica, destaca a complexidade dos fenómenos, é sensível ao crescimento das desigualdades e às novas problemáticas que afligem a sociedade neste fim de século.

Mendez contesta claramente explicações de sentido único, por mais de uma vez faz notar como certas previsões sonoras, como o fim das grandes aglomerações, o advento da dispersão e do tele-trabalho não se verificam, pelo menos não com aquela rapidez que os seus autores prediziam, porque os fenómenos humanos são marcados pela complexidade e pela contingência.

Partindo do primado do económico não adopta uma visão economicista porque o económico é ponderado por preocupações de índole social. De facto o enfoque é muito centrado nas estratégias das empresas e nas políticas públicas alheando-se das dimensões culturais e simbólicas associadas aos novos modos de socialização e estilos de vida, considerados por CLAVAL (1993) componentes importantes da visão não economicista da sociedade, que talvez pudessem encontrar algum lugar nesta obra, designadamente no capítulo 7. Mas não há dúvida que as fronteiras entre a geografia económica e a geografia social por vezes entram em colapso, pois as mudanças na economia estão a pôr novos problemas sociais e no equilíbrio entre os territórios. $\mathrm{O}$ aumento das desigualdades, a distância crescente entre regiões ganhadoras e perdedoras, as estratégias de desenvolvimento regional, o crescimento da pobreza, estão presentes ao lado das inovações, do desenvolvimento das novas tecnologias da informação, da maior facilidade de circulação do capital e do crescimento do comércio internacional. Em termos de temas pode dizer-se que o maior destaque vai para as inovações tecnológicas e a reestruturação dos mercados de trabalho.

As preocupações didácticas subjacentes e as ideias chaves que destaquei ajudam a explicar a organização do livro que se demarca nitidamente dos manuais clássicos da geografia económica compartimentados por actividades, para pôr no centro a compreensão das grandes questões do nosso tempo.

${ }^{3}$ La Géographie au temps de la chute des murs. Paris. L'Harmattan. 
Nos três primeiros capítulos de carácter introdutório, o autor passa em revista os objectivos e os enfoques que caracterizam a geografia económica, e apresenta o sistema capitalista numa perspectiva de desenvolvimento histórico, com uma sucessão de períodos de expansão e de crises, e respectivas interpretações, completado com os padrões de organização espacial das actividades induzidos pela consolidação deste sistema.

O capítulo 4 baliza a mudança do último quarto de século traduzido na globalização económica. Os capítulos 5 e 6 dão conta das duas faces da reestruturação, no primeiro apresenta a importância, significado e conteúdo da inovação tecnológica; no 6 analisa a nova divisão internacional do trabalho, as tendências recentes do emprego, as políticas adaptadas pelos vários países e o futuro previsível do trabalho.

No capítulo 7, dedicado aos padrões espaciais das actividades, considera os modelos de localização desde os modelos tradicionais, como os de Von Thunen, Webber, Christaller, até aos enfoques mais recentes sobre o processo de decisão nas empresas e a difusão de inovações, assuntos que são complementados com uma análise da alteração registada nos padrões da indústria e dos serviços, terminando com uma nota sobre as novas formas de comércio e alterações no consumo.

Finalmente, o capítulo 8, que remata o livro, trata a questão das desigualdades. Passa em revista as teorias de explicação, mais uma vez das mais clássicas às mais modernas, as políticas de desenvolvimento regional e local, para terminar com a questão da relação entre crescimento económico, ambiente e desenvolvimento sustentável.

Contido no grafismo, este manual possui alguns quadros muito utéis que sistematizam de forma resumida as ideias expostas. Cada capítulo é acompanhado da respectiva bibliografia específica, incorporada depois na extensa bibliografia que remata o volume.

Trata-se de um livro fascinante, com uma estrutura muito bem articulada, apresenta os temas mais actuais com uma linguagem acessível sem nunca perder o rigor, coisa só possível em alguém que, dominando em profundidade os assuntos, possui espírito de síntese, uma grande experiência como professor e um sentido pedagógico da escrita, Lê-se por isso com enorme prazer e é, indiscutivelmente, uma obra muito útil para um leque muito amplo de interessados. Em primeiro lugar é útil para os estudantes e professores de geografia económica porque aqui encontram uma síntese das ideias actuais, uma plataforma de discussão e uma riquíssima orientação para leituras mais profundas e especializadas; para os geógrafos especializados noutras áreas, assim como para outros investigadores, a sua utilidade é talvez ainda maior pelo leque de temas que reúne, a forma concisa como ajuda a compreender o processo geral de mudança societal que impecavelmente vai desdobrando diante de nós, passando pela apresentação das correntes teóricas mais relevantes na explicação dos vários temas. 